\title{
Chinese and British Diplomatic Gifts in the Macartney Embassy of 1793 Henrietta Harrison
}

Princes are only or ought only to be be known by their bounty to their subjects, and not by their subjects bounty to them - their minds should be too exalted to stoop to such Trifles ${ }^{1} \quad$ Lord Macartney

I do not value curious objects or attend to the boasted precision of the devices. I embrace those who come from afar bringing only a few trifles and reward them generously on their departure. ${ }^{2} \quad$ The Qianlong Emperor

In these words the two leading participants in Britain's first embassy to China reflected on the proper role of gifts in the embassy. Lord Macartney was drafting a response to the charge that the embassy would have been more successful if he had taken diamonds and pearls from India as gifts. The Emperor was composing a poem on the evening of his reception of the same British embassy. At a first reading, what is striking about the two statements is their similarity: both Macartney and the Qianlong emperor are clear that rulers should display their own generosity and treat the gifts they receive as trifles, but beneath these similarities lie quite different ideas of gift giving. Macartney was writing at a time when the giving and receiving of valuable presents was a key political issue within the British state and he himself was building a career on a reputation for incorruptibility. He goes on to argue that for a prince to accept a valuable gift would imply a return, which might well be political office 'very improperly bestowed.' The Qianlong emperor was quoting a famous text from the ancient Book of Documents (Shang shu) on the proper response to gifts from envoys. It contains a speech arguing that only a virtuous prince who values what is useful rather than curious objects will really be able to influence those outside his state to pay homage. ${ }^{3}$ The cultural connotations are far apart, but the sentiments are similar: rulers should regard the precious gifts they receive as trifles of little inherent value. Both the Chinese and English words also imply that while this is a proper attitude in a ruler, diplomatic gifts do in fact have value and should be reciprocated.

Gifts have long been seen as central to the Macartney embassy because a classic interpretation of traditional China's international relations focuses on the Chinese reception of foreign diplomatic gifts. John K. Fairbank and Teng Ssu-yu argued in the 1940s that gifts were understood as tribute that served to legitimise a China-centered world order that was violently disrupted by the rise of the European

\footnotetext{
I am grateful to the Royal Collection Trust for their enthusiasm and assistance, and to seminars at the Faculty of Asian and Middle Eastern Studies at the University of Cambridge, the Institute of Historical Research at the University of London, the Department of Sinology at KU Leuven, the History Department of Peking University, and the History Department at Sichuan University for comments on earlier versions of this article.

${ }^{1}$ Bodleian Library, Oxford, MS Eng misc f 533:16 Macartney Commonplace Book.

${ }^{2}$ Yingshi Magaerni 英使馬嘎爾尼訪華檔案史料匯編 [Collected archival materials on the English envoy Macartney’s visit to China] (Zhongguo di yi lishi dang’anguan 中國第一歷史檔案館 ed. Beijing: Guoji wenhua chuban gongsi, 1996), p. 52. See also X. Ye, “Ascendant Peace in the Four Seas: Tributary Drama and the Macartney Mission of 1793” Late Imperial China xxvi (2005), p. 104; J. Needham and L. Wang, Science and Civilisation in China vol 4.2 Mechanical Engineering (Cambridge: Cambridge University Press, 1965), p. 477.

${ }^{3}$ Shang shu 尚書 [Book of documents], Zhou shu, lü ao 周書, 旅獒.
} 
powers in the nineteenth century. ${ }^{4}$ This argument drew heavily on a manual for central government administration in the Ming and Qing dynasties known as the Collected Statutes (Huidian), which laid down general rules for court visits by foreign embassies. ${ }^{5}$ Based on this normative text, the Macartney embassy and the Qianlong emperor's apparent dismissal of gifts designed to represent the rising British state became a convenient peg on which to hang a much larger history of China's failed encounter with the modern world. ${ }^{6}$ Further study of Qing diplomacy has long since led to more nuanced versions of this 'tribute system' model, most notably by John E. Wills Jr, who limits the practice of the system to China's relations with certain East Asian states in the period from 1420 to 1550, and James Hevia whose most recent work stresses that the ideal of foreign countries coming to give tribute was nevertheless important for the later Qing dynasty. ${ }^{7}$ Meanwhile China's economic growth in recent years has begun to undermine many mid-twentieth century historical narratives designed to explain the country's failure to modernise succesfully. ${ }^{8}$

Despite these changes in the surrounding historiography, studies of the gifts given during the Macartney embassy have continued to interpret them as symbols of Qing China's failure to acknowledge and learn from the evidence it received of rising British power. $^{9}$ Meanwhile, studies of early-modern European diplomacy have been enriched by a new interest in gift giving as part of the cultural aspects of diplomatic encounters. ${ }^{10}$ Shifting our focus to this and thus including the Chinese as well as the British gifts given during the embassy shows how British and Chinese attitudes to the gifts interacted. It becomes clear that tribute was a European concern that was mapped onto a much looser set of Chinese terms. Moreover, rather than emphasizing cultural collision and the Chinese dismissal of British gifts, we see that the value of both British and Chinese gifts was defined through the ongoing trade between the two countries and the knowledge this generated. Most of the most costly gifts were not hitherto unknown items, but rather goods already known to be highly valued in the trade.

This approach also suggests that we should think about the gifts given during the embassy as an element in the negotiations. Although these have been seen as a

\footnotetext{
${ }^{4}$ J. K. Fairbank and S.Y. Teng “On the Ch’ing Tributary System” Harvard Journal of Asiatic Studies vi (1941), pp, 135-246.

${ }^{5}$ The relevant edition here is Qinding da Qing huidian 欽定大清會 [Imperially authorised collected statutes of the great Qing] ed. Yun Tao 允祹 et al. (1764. Taibei: Taiwan shangwu yinshuguan, 1986 reprint), juan 56, pp. 1-12.

${ }^{6}$ S.Y. Teng and J.K. Fairbank, China's Response to the West: A Documentary Survey (Cambridge: Harvard University Press, 1961), pp. 18-20.

${ }^{7}$ J.E. Wills, Embassies and Illusions: Dutch and Portuguese Envoys to K'ang-hsi 1666-1687 (Cambridge: Council on East Asian Studies, Harvard University, 1984), pp. 173-5, 187; J.L. Hevia, Cherishing Men from Afar: Qing Guest Ritual and the Macartney Embassy of 1793 (Durham: Duke University Press, 1995); J.L. Hevia, “Tribute, Asymmetry, and Imperial Formations: Rethinking Relations of Power in East Asia” in J.E. Wills Jr. ed, Past and Present in China's Foreign Policy: From 'Tribute System' to 'Peaceful Rise' (Portland: MerwinAsia, 2010), pp. 61-76.

${ }^{8}$ H. Harrison, “The Qianlong Emperor's Letter to George III and the Early Twentieth-Century Origins of Ideas about Traditional China's Foreign Relations” American Historical Review (forthcoming 2017).

${ }^{9}$ J.L. Cranmer-Byng and T.H. Levere, “A Case Study in Cultural Collision: Scientific Apparatus in the Macartney Embassy to China” Annals of Science xxxviii (1981), pp. 503-25; M. Berg, “Britain, Industry and Perceptions of China: Matthew Bolton, 'useful knowledge' and the Macartney Embassy to China 1792-94” Journal of Global History i (2006), pp. 269-88.

${ }^{10} \mathrm{C}$. Windler, La diplomatie come éxperience de l'autre: Consuls français au Maghreb (1700-1840) (Genève: Droz, 2002); F. Heal, The Power of Gifts: Gift Exchange in Early Modern England (Oxford: Oxford University Press, 2014).
} 
failure because the British did not achieve their negotiating aims, they could equally well be seen as a success for the Chinese, who evaded British demands for territory and tax reductions while placating the ambassador with gifts, courtesies, and vague promises for the future. Within the negotiations that led to this result, gifts displayed the giver's wealth and power while simultaneously complimenting the recipient. The balance between competitive display and conciliation depended on the openness of the gifts as material objects to multiple interpretations that would enable both sides to accept the outcome. ${ }^{11}$ As a result attempts to fix the meaning of the gifts in order to convey complex messages about the sources of the giver's power were most unlikely to succeed. This point is reinforced by the ultimate disappearance of both British and Chinese gifts into vast royal collections of similar objects.

The gifts for the Macartney embassy were chosen in the context of significant economic and political interests on both sides, most notably the tea trade and the rise of British maritime power. Accounts of the embassy have tended to downplay these interests and have emphasized the British concern with sovereign equality between the two countries, of which Lord Macartney's refusal to perform the ceremonial kowtow was a symbol. However, the primary aim the embassy was to benefit the East India Company's trade. The tea trade was not merely immensely profitable in itself, but was also part of the mechanism of Company rule in India. It was by investing in tea shipments from Guangzhou (Canton) that the profits of Indian empire both taxes and private fortunes were transmitted back to England. Moreover, the embassy took place at the time when the East India Company was making the transition from merchant enterprise to an arm of the state and as a result its profitability was a significant concern for the British government. As one internal government document put it 'although the avowed and ostensible purpose of the Embassy is compliment and conciliation, We hope that means may be found to secure substantial priviledges and advantages for the Company. ${ }^{12}$

In effect this meant that the British government hoped to increase the size of the trade and reduce the amount of money that the Qing state was extracting from it, primarily by getting permission to trade outside Guangzhou and thus breaking the monopoly through which the Qing taxed the trade. To this end the British requested an island off Zhejiang province as a commercial base. They wanted an ambassador in Beijing, for the same reason, that is to enable their merchants to bypass the officials in Guangdong who controlled and taxed the trade. ${ }^{13}$ However, the trade was also a major source of income for the Qing emperor's privy purse. At a time of great financial pressures caused by a series of wars, including those against the Gurkha state expanding on the borders of Tibet, the Qing had an obvious interest in maintaining this income and wished to avoid changing the existing arrangements. ${ }^{14}$

\footnotetext{
${ }^{11}$ H. Liebersohn, The Return of the Gift: European History of a Global Idea (Cambridge: Cambridge University Press, 2011); N.Z. Davis, The Gift in Sixteenth-Century France (Oxford: Oxford University Press, 2000); N. Di Cosmo, "Kirghiz Nomads on the Qing Frontier: Tribute, Trade, or Gift Exchange” in Di Cosmo and D.J. Wyatt eds. Political Frontiers, Ethnic Boundaries, and Human Geographies in Chinese History (London: RoutledgeCurzon, 2003), pp. 351-72.

${ }^{12}$ British Library, I[ndia] O[ffice] R[ecords] G/12/91, pp. 107-8, Draft to the new commissioner in Canton. See also IOR/G/12/91, pp. 23-4, Macartney to Dundas, 4 Jan. 1792. See also H.V. Bowen, The Business of Empire: The East India Company and Imperial Britain, 1756-1833 (Cambridge: Cambridge University Press, 2006), pp. 222-34.

${ }^{13}$ IOR/G/12/92, pp. 259-62, Macartney to Cho-chan-tong, 3 Oct.1793.

${ }^{14}$ P.M. Torbert, The Ch'ing Imperial Household Department: A Study of its Organization and Functions, 1662-1796 (Cambridge: Council on East Asian Studies, Harvard University, 1977), pp. 98-
} 
British naval power, demonstrated both by the warship that brought the embassy and the model of an even larger and more heavily armed ship that was presented to the emperor, meant that a flat rejection of the British demands carried a significant risk.

In this context, the gifts given by both sides were intended to demonstrate in material form the wealth and power of the givers and the splendour of their generosity, while at the same time flattering and conciliating the recipients. The existence of the trade meant that most of the items given as gifts had a known market value in Guangzhou and each side knew what kind of objects were most highly valued by the other. The British exported to China woollen textiles and clockwork. George Leonard Staunton in his account of the embassy, says that the British presents were chosen quite explicitly on the basis of 'what was known to be in the greatest demand, and to bring the highest profit' in Guangzhou, which was 'extraordinary pieces of ingenious and complicated mechanism, set in frames of precious metal, studded with jewels, and producing, by the means of internal springs and wheels, movements apparently spontaneous.' 15 The demand for such items in Guangzhou was partly driven by the emperor's known enthusiasm for them and willingness to accept them as gifts. ${ }^{16}$ The Chinese exported tea to Britain but also silk, cotton, and porcelain. When they gave these items as gifts the British had a sense of their value and reacted accordingly. ${ }^{17}$ This emphasis on market value meant that the total amount of money spent on the embassy was also of interest to both sides.

The British initiated the embassy and set the standard. Their aim was to impress the Chinese with Britain's wealth and civilisation and to promote British manufactures. When this was combined with the wealth of the East India Company and the pretensions of Macartney to high office the result was spectacular. For the Company the gifts could be seen as a speculation on the potential profits of the embassy if the negotiations succeeded. These were huge: at one point Macartney considered that even a single ship being allowed to load its return cargo tax-free in Zhejiang, rather than in Guangzhou, would cover most of the cost of the embassy to the Company. ${ }^{18}$ Previous studies of the embassy's gifts tend to imply that the most important gifts were scientific instruments. ${ }^{19}$ However, when they were purchased in London the most expensive British gifts were textiles, mainly high quality woollen broadcloths strongly symbolic of England, which cost £2,020 to purchase. The next most costly item was a pair of summer and winter carriages for the emperor $(£ 1,656)$. These were put on display in London, where Fanny Burney went to visit them, before they were packed up and sent off to China. Third in terms of cost was the most valuable scientific item, the planetarium, which was a combined clock, globe and orrery designed and built by a German pastor and redecorated by Benjamin Vulliamy, clock maker to George III $(£ 1,384)$ (fig. 1). Other costly gifts were a pair of globes (£971), a pair of chandeliers (£949), and various guns and pistols (£939) (fig. 2).

99. See also M. Mosca, From Frontier Policy to Foreign Policy: The Question of India and the Transformation of Geopolitics in Qing China (Stanford: Stanford University Press, 2013).

${ }^{15}$ George Leonard Staunton, An Authentic Account of an Embassy from the King of Great Britain to the Emperor of China (London: W. Bulmer, 1797. $4^{\circ}$ ), I. 42.

${ }^{16}$ Dong Jianzhong 董建中, “Chuanjiaoshi jingong yu Qianlong huangdi de xiyang pinwei” 傳教士進 貢與乾隆皇帝的西洋品味 [Tribute presented by missionaries and the Qianlong emperor’s taste for Western exotica] Qingshi yanjiu 清史研究 [Qing history research] iii (2009), p. 100.

${ }^{17}$ E.g. Aeneas Anderson, A Narrative of the Embassy to China in the Years 1792, 1793, and 1794 (London: Debrett, 1795), pp. 148-9.

${ }^{18}$ IOR/G/12 /92, p. 81, Macartney to Dundas, 9 Nov. 1793.

${ }^{19}$ Cranmer-Byng and Levere, "Case Study in Cultural Collision”; S. Schaffer, "Instruments as Cargo in the China Trade” History of Science xliv (2006), pp. 217-46. 
Smaller gifts bought in London included fashionably decorated clocks and watches, sadlery, prints, fine porcelain, paper, and painted wall hangings. ${ }^{20}$ After reaching China, Macartney soothed the anxieties of the senior East India Company merchants in Macao, who benefitted from the existing monopoly arrangements, by buying items including a Herschel reflector telescope and a Parker burning lens from them for $£ 3,582{ }^{21}$ The embassy also presented six brass cannon and two mortars which were provided by the government rather than paid for by the East India Company. ${ }^{22}$ In addition to these items, the embassy took over gifts that had originally been supplied to the earlier Cathcart embassy to China, which failed after the ambassador died on the journey out. Cathcart had set off with a more conventional set of gifts that included silver-mounted guns, spectacles, opera glasses, microscopes, watches, and a gold box mounted with large diamonds and decorated with enamel. ${ }^{23}$ In China expectations of the British gifts were already high before the embassy arrived, probably because of the known value of the British trade. Travelling up to the emperor's palace beyond the Great Wall, the embassy was approached by an official who asked to see the presents, having heard rumours that the gifts included a chicken fed on coal, a dwarf, an elephant the size of a cat, and a pillow that could transport the sleeper to the place of his dreams. ${ }^{24}$

The splendour of the British gifts influenced how the Qing responded. As was the case with the gifts offered by the English, fine textiles in huge quantities were prominent among the Chinese gifts. Silk was a traditional Chinese export and was a staple of gifts to foreign embassies in the seventeenth and early eighteenth centuries. ${ }^{25}$ The most valuable silks were sent to King George III, including brocade woven to make up a magnificent dragon robe. Macartney and his retinue also received gifts of valuable satins, silks, and gauzes. At the lowest end of the scale came the lengths of Korean cotton cloth presented to each of the 600 sailors who waited for the embassy aboard the English ships off the coast. ${ }^{26}$ Unlike the gifts given by the British, the Chinese textiles were not purchased but came from the Imperial Household Department, which stored items received by the emperor from across the empire and beyond. Their places of origin were included in the gift list, and demonstrated the

${ }^{20}$ IOR G/12/91 pp. 281-99, Records of sundry articles purchased by Francis Baring (The sums have been calculated from several entries and are intended to give a general indication of the relative values. Items that were purchased, but not presented have not been included.); Fanny Burney, The Journals and Letters of Fanny Burney (electronic edition), ed Joyce Hemlow et al. (Charlottesville: Intelex Corporation, 2002) I. 206; J. Roberts ed., George III and Queen Charlotte: Patronage, Collecting and Court Taste (London: Royal Collection Publications, 2004), p. 296.

${ }^{21}$ IOR/G/12/92 p. 387, Macartney to the Chairman and Directors of the EIC, 23 Dec. 1793; IOR/G/12/93, II. 219, Secret Committee, 31 June 1793; E.H. Pritchard, "The Instructions of the East India Company to Lord Macartney on his Embassy to China and his Reports to the Company 1792-4" Journal of the Royal Asiatic Society of Great Britain and Ireland iv (1938), p. 508; Ithaca, Cornell [University Library, Original] Manuscripts, [Papers and Letters] relating to Macartney Mission [to China, 1792-1794], vol. 2 doc. 27, Letter from the Directors of the EIC to Macartney, undated. ${ }^{22}$ IOR/G/12/92, p. 166, Catalogue of Presents sent by His Britannic Majesty to the Emperor of China; IOR/G/12/91, p. 43 Macartney to Dundas, 23 Jan. 1792; Yingshi Magaerni, p. 563.

${ }^{23}$ IOR/G/12/91, pp. 301-4, Account of sundry articles purchased in the year 1787 for the late Colonel Cathcart's Embassy to China.

${ }^{24}$ J.C. Hüttner, Voyage a la Chine (Paris: J.J. Fuchs, 1798), p. 61-3.

${ }^{25}$ Qinding da Qing huidian shili 欽定大清會典事例 [Official collected statutes and precedents of the great Qing] ed. Kun Gang 崑岡 et al. (Beijing: Waiwubu, 1899), juan 506-7. C.f. C. Anderson, "Material Mediators: Johan Maurits, Textiles and the Art of Diplomatic Exchanges” Journal of Early Modern History xx (2016), pp. 63-85.

${ }^{26}$ IOR/G/12/92, pp. 318, 338, Catalogue of the Emperor of China’s presents; Yingshi Magaerni, pp. 96, 155. 
emperor's position as pivot in a world of gift exchange that brought him not only the characteristic products of each Chinese province but also cotton and paper from Korea, the seeds of the sweet melons from central Asia, and sugar from Tibet. However, this did not mean there was a lack of awareness of their likely market value to the British recipients: the Korean cotton cloth found in such quantities in the imperial stores that it sometimes had to be sold off to prevent it rotting away was given to the lowest ranking British sailors at the emperor's personal suggestion and was not much appreciated by them either. ${ }^{27}$

Other gifts presented to the embassy reflected the Qianlong emperor's wellknown enthusiasm as a collector of rare and precious objects. From the 1750 s he had begun to present these items in significant numbers to foreign embassies. ${ }^{28}$ On this occasion he gave items of sandalwood and cloisonné, as well as jade, porcelain, fans, incense, and lacquerware. Not only were these presented in large quantities, but surviving examples suggest their impressive size and high quality (see figs 3, 4 and 5). ${ }^{29}$ The nature of the trade with the British clearly influenced how these gifts were selected. The first item on the gift list was a sandalwood and cloisonné ship. Cloisonné was a European technique that the Chinese had recently adopted, while sandalwood was an important item in the trade conducted by British merchants between India and China. ${ }^{30}$ The porcelain included items in what the Chinese described as being in the Western style, such as a pair of vases on one of which two gentlemen and a servant in European dress wander in a Chinese landscape (fig 4). ${ }^{31}$ The Burmese embassy who were present at the same time were also given items associated with their country: a statuette of the Buddha, a copy of a Buddhist scripture, and a set of prayer beads. ${ }^{32}$ The British also received a number of relatively unusual items that appear to have been chosen in direct response to their own gifts: a set of pictures of Qing battles (a subject emphasized in the Chinese descriptions of the British prints), furniture, lanterns, and sword blades. ${ }^{33}$

Although individual items were beautiful, rare and costly, it was the scale of the Chinese gifts to the British that was most impressive. Far more was given than to other embassies during this period. The difference is suggested by the quantities of silk textiles: in 1753 the Portuguese received 472 bolts of satin, silk and gauze as gifts for their king, a large amount compared to what was given to most embassies, but only half the number sent to George III in $1793 .{ }^{34}$ When the gifts to the British were put out on display, the emperor ordered his officials not to let the Burmese envoys see how many there were. ${ }^{35}$ The Burmese ruler had been given just twelve bolts of satin and thirty fans as opposed to the 316 given to the British. ${ }^{36}$ The scale of the

\footnotetext{
${ }^{27}$ Yingshi Magaerni, p. 155; He Xinhua 何新華, Qingdai gongwu 清代貢物制度研究 [Research on the Qing tribute system] (Beijing: Shehui kexue wenxian chubanshe, 2012), p. 201; British Library, Add MS 21106, Ernest Gower, A Journal of His Majesty’s Ship Lion 1792-4, p. 108.

${ }^{28}$ Qinding da Qing huidian shili, juan 506-7.

${ }^{29}$ IOR/G/12/92 pp. 317-348, Catalogue of the Emperor of China’s presesnts; Yingshi Magaerni, pp. 96-106.

${ }^{30}$ He, Qingdai gongwu, pp. 135, 444; H.B. Morse, The Chronicles of the East India Company Trading to China, 1635-1834 (Oxford: Clarendon Press, 1926-29), II. 201.

${ }^{31} \mathrm{~J}$. Ayers, Chinese and Japanese Works of Art in the Collection of Her Majesty The Queen (London: Royal Collection Trust, 2016), I. 298-9; Yingshi Magaerni, p. 96.

${ }^{32}$ Qinding da Qing huidian shili, juan 507, p. 24.

${ }^{33}$ IOR/G/12/92, pp. 317-48, Catalogue of the Emperor of China's presents; Yingshi Magaerni, pp. 96105, 110-11, 134-7, 150-1.

${ }^{34}$ Da Qing huidian shili, juan 506, p. 12, juan 507, p. 3-4.

${ }^{35}$ Yingshi Magaerni, p. 95; Hüttner, Voyage a la Chine, p. 89.

${ }^{36}$ Da Qing huidian shili, juan 507, p. 24.
} 
emperor's generosity to the British was also emphasized by the number of different occasions on which the gifts were given. The first and largest number of gifts were sent to reciprocate the British king's gifts, but significant further sets were given at the audience for the emperor's birthday, when Macartney was invited to attend a feast, when he was given a tour of the imperial gardens, as the embassy left Beijing, on several occasions during the journey south, and on the embassy's arrival in Guangzhou. ${ }^{37}$ These later sets, which were part of standard imperial practice in the reception of important embassies, overwhelmed reciprocity, since all the British gifts had already been presented.

Overall, the very grandeur of the British gifts created a situation where the Qianlong emperor would both respond with spectacular gifts of his own and downplay the gifts that he received, and the British would do the same to the Chinese gifts. It is this interaction which, when only the Chinese response is considered, created the illusion that the emperor underrated the British gifts. In fact the opposite is the case: the scale of the Chinese gifts suggests how important it was to the Qing to handle the embassy successfully.

The value and splendour of the gifts increased the importance to both sides of controlling their interpretation. However, working between two cultures and languages this was all but impossible to achieve. This is not just a question of understanding how the Chinese thought about the British gifts; British attitudes also mattered, especially the fear of being seen to pay tribute to the Chinese. As historians have long been aware, the cultural structures through which power was expressed in Britain and China were very different and neither could be simply expressed in the terms of the other. However, the way in which the terms were translated mingled these two sets of ideas and has shaped much later scholarship on the embassy.

The disputes about how to define the British gifts during the embassy have conventionally been understood as a reflection of Chinese attitudes to foreign countries, but ideas about gifts in the domestic politics of both Britain and China also played an important role. Gifts reflected, created, and made visible relationships, but left it unclear what exactly those relationships were. Felicity Heal argues for the emergence of this as a problematic issue in England in the sixteenth century, with the beginnings of a transition from a politics structured around personal loyalties to one of bureaucratic government. ${ }^{38}$ This insight is also helpful in understanding attitudes in China. There too valuable gifts cut across bureaucratic structures and could undermine ideals of virtuous rule.

The problem of whether the British gifts were understood as tribute began almost as soon as the embassy arrived in China. It was embodied for the British in the question of whether the Chinese had described their gifts using the word gong 貢. As the embassy travelled upstream from Tianjin towards Beijing, the interpreter Li Zibiao told Macartney that the Chinese barges carrying the embassy were inscribed with the character gong, which he translated 'tribute.' (Or probably 'tributo' since Li, a Chinese priest trained in Naples, spoke to Macartney in Italian). Macartney decided

\footnotetext{
${ }^{37}$ Anderson, Narrative of the Embassy to China, pp. 148-9, 152-4, 213; IOR/G/12/92, pp. 317-48, Catalogue of the Emperor of China’s presents; Yingshi Magaerni, pp. 477-9, 486-7; Rome, A[rchivium] P[ropaganda] F[ide], S[critture] O[riginale della] C[ongregazione] P[articolare Indie Orientali e Cina], LXVIII. 618, Jacobus Ly, 20 Feb. 1794.

${ }^{38}$ Heal, Power of Gifts, pp. 197-8.
} 
to ignore the matter unless it was forced to his attention. ${ }^{39}$ In his account defending Macartney's position, Staunton rejected the translation of gong as tribute and claimed that the Chinese terminology was merely old fashioned in comparison with European practice, and reflected that in the court of the Habsburg Holy Roman Emperor. ${ }^{40}$ Meanwhile, the Qianlong emperor was very clear that Macartney should be described as an envoy bringing gifts (gongshi 貢使) rather than an imperial commissioner (qinchai 欽差). The translations of the English documents into Chinese had used this latter term, which implied a close personal relationship to the ruler and was considered especially inappropriate after Qing officials discovered that Macartney was not actually related to the English king. However, like Macartney, the emperor chose not to make an issue of the terminology. ${ }^{41}$ After the embassy arrived in Beijing, the British gifts were set up for display in the Yuanmingyuan palace, and while this was being done there was a dispute between the Chinese workmen and the British over how they should be handled. The Chinese workmen, with the backing of Zhengrui, a senior Manchu in charge of the embassy's reception, claimed authority on the grounds that the gifts were gong and therefore belonged to the emperor. The interpreter Li Zibiao mediated this by saying that the gifts were not gong but $l i$ 禮 a word for gifts that stresses their ritual propriety. Zhengrui's superior Jin Jian, a more flexible Korean known for his innovative use of movable type for a major printing project, accepted this alternative. ${ }^{42}$

The English word tribute drew its meaning from the Latin tributum which originally meant simply a tax but later came to refer to a specific tax paid by the provinces of the Roman empire to Rome. ${ }^{43}$ Eighteenth-century British authors, familiar with the classical texts, often used the word in the broad sense of a tax, for example to refer to excise duties on wine. ${ }^{44}$ After the fall of the Roman empire, tribute came to refer to gifts presented by one ruler to another as a sign of submission. Tribute in medieval Europe was inherently ambiguous in that it was presented as a gift, understood as noble, and handed over in public, but it was a gift paid as a duty and might potentially be enforced by warfare. ${ }^{45}$ The forms of medieval tribute continued as a minor aspect of diplomatic relations in Europe through the early modern period, and were relatively unproblematic in the context of an accepted hierarchy of princes. However by the 1790s this hierarchy was being successfully contested within Europe and payments that were understood as tribute to the Ottoman Empire were particularly problematic. ${ }^{46}$ Christian Windler has argued that in their demands for recognition, and later for equality of status among all states engaged in diplomacy, Britain and France began to emphasize the idea of presents between rulers as free gifts that should be understood as symbols of the nation. He analyses the impact of such changes on the relations between France and the Beys of Tunis. In

\footnotetext{
${ }^{39}$ Macartney, Embassy to China, p. 88; John Barrow, Auto-biographical Memoir of Sir John Barrow, Bart., Late of the Admiralty (London: John Murray, 1847), p. 66; Archivio Istituto Universitario Orientale Napoli, 16/1/16, Paulus Cho cum Jacobus Ly, 22 May 1792.

${ }^{40}$ Staunton, Authentic Account, II. 239. See also Hüttner, Voyage a la Chine, p. 22.

${ }^{41}$ Yingshi Magaerni, pp. 40, 124.

${ }^{42}$ Macartney, Embassy to China, p. 97.

${ }^{43}$ Oxford Latin Dictionary (Oxford: Clarendon Press, 1982). See also Hevia, Cherishing Men from Afar, p. 10; Zhang Shuangzhi 張隻智, Qingdai chaoqin zhidu yanjiu 清代朝勤制度研究 [Research into the Qing tribute system] (Beijing: Xueyuan chubanshe, 2010), pp. 279-86.

${ }^{44}$ E.g. The Free Briton, 25 Jan. 1732.

${ }^{45}$ T. Reuter, "Plunder and Tribute in the Carolignian Empire" Transactions of the Royal Historical Society iiiv (1985), pp. 75-94.

${ }^{46}$ Heal, Power of Gifts, p. 150.
} 
this context French consuls continued to make gifts but attempted to explain them not as tribute to the Ottoman empire but as free gifts and representations of their own superiority. ${ }^{47}$ Thus the issue of whether gifts were tribute was particularly important in relation to Asian rulers. To call the gifts given to the Chinese emperor tribute was even more problematic from the British perspective because their high value would then imply greater subjection rather than greater power.

For the Chinese, the key terms used for political gifts were gong, which means to give, and tan 貪, which means to desire greedily. These were closely related to an important set of ideas around the relationships of host and guest, in which the emperor's power was expressed by his position as host and all those who visited him were his guests. Unlike tribute, the Chinese words gong and tan are primarily verbs and both they and the idea of hosting focus attention on the actor rather than the object.

Gong was conventionally used for presenting gifts to the emperor. Discussion of this term in a diplomatic context has been drawn largely from the section on visits by foreign envoys in the Collected Statutes of the Qing. It uses gong for the envoys' gifts to the emperor, and $c i$ 賜 (bestowal) for the gifts that the emperor gave in return. ${ }^{48}$ Hevia interprets these terms as keys to understanding the model of kingship during the Qing and thus also China's foreign relations. ${ }^{49}$ However, as several scholars have noted in recent years, the term gong had a much broader remit than this implies. In particular it was not primarily associated with foreign relations: gong was used for all gifts to the emperor. In the eighteenth century the right to give such gifts was confined to a limited number of high status individuals: members of the imperial household and clan, senior officials, and the rulers of territories that were either on the fringes of or beyond the empire. The vast majority of gifts came from senior officials. ${ }^{50}$ As the relatively easy resolution of the dispute over the use of the terms gong or li during the embassy shows, gong was not a politically sensitive term during this period and could plausibly be replaced by other words without arousing concern.

The translation of gong as 'tribute' predates the Macartney embassy, and thus mattered to its members, but, as Staunton argued, the two terms are far from being an exact match. Some items presented as gong were undoubtedly an expression of political submission. The best example of this is Korea, which regularly presented significant quantities of goods, some of which on this occasion the Qianlong emperor passed on as gifts to the British. These Korean gifts were imposed after a military conquest, maintained by threat of force, and resented by Koreans, who did not regard the Manchu Qing as legitimate heirs to the previous dynasty. ${ }^{51}$ Moreover, the Collected Statutes lays down that the gifts given by envoys should be local products, which resonated with European ideas of tribute. ${ }^{52}$ But from a British perspective

\footnotetext{
${ }^{47}$ C. Windler, “Tributes and Presents in Franco-Tunisian Diplomacy” Journal of Early Modern History iv (2000), pp. 168-99; D. Carrió-Invernizzi, “Gift and Diplomacy in Seventeenth-century Spanish Italy” Historical Journal li (2008), pp. 881-99.

${ }^{48}$ Qinding da Qing huidian, juan 56, pp. 1-3.

${ }^{49}$ Hevia, “Tribute, Asymmetry, and Imperial Formations”, p. 71.

${ }^{50}$ Dong Jianzhong 董建中, “Qing Qianlong chao wanggong dachen guanyuan jingong wenti chutan” 清乾隆朝王公大臣官員進貢問題初探 [A preliminary exploration of the question of giving tribute by princes, ministers and officials in reign of the Qing Qianlong emperor] Qingshi yanjiu 清史研究 [Qing history research] i (1996), pp. 40-50; L. Hostetler, Qing Colonial Enterprise: Ethnography and Cartography in Early Modern China (Chicago: University of Chicago Press, 2001), p. 43.

${ }^{51}$ A. Schmid, “Tributary Relations and the Qing-Choson Frontier on Mount Paektu” in D. Lary ed., Chinese State at the Borders (Vancouver: UBC Press, 2007), pp. 126-42.

${ }^{52}$ Qinding da Qing huidian, juan 56, p. 3.
} 
other gifts termed gong were simply taxes, as when Qing provincial officials were required to provide certain quantities of a given local product on a regular schedule. Moreover, gong was also used for a gift given for a special occasion that was equally reciprocated, which was precisely what the British would have described as a present. ${ }^{53}$ Overall gong was a much looser and broader term than tribute.

It is worth noting here, that the idea that tribute was characteristic of Qing China's foreign relations has had the effect of making the English term much more common in descriptions and even translated texts than the Chinese term gong. A careful examination of the famous letter from the Qianlong Emperor to George III, which is his official response to the embassy, shows that while 'tribute' occurs several times in the standard English translation it is used for several linguistically unrelated Chinese terms related to gifts and visits by foreign envoys. ${ }^{54}$ Although this translation dates from the early twentieth century, it is representative of the literature as a whole, which has limited the Qing understanding of the embassy's gifts to British tribute and imperial bestowals in response.

For the Chinese, there were also other important concepts through which gifts were understood at the time. He Xinhua in his study of gifts given to the Qing emperors argues that hosting is the primary metaphor of these rituals, as is suggested by the inclusion of the reception of foreign envoys in the section of the Collected Statutes on rituals for receiving guests. ${ }^{55}$ Throughout their time in China the Macartney embassy received lavish hospitality. By presenting himself as the host the emperor retained a culturally-sanctioned position of superiority. Macartney received several personal gifts of food and drink from the emperor. At the banquet in Rehe, the emperor sent dishes and wine from his own table, and presented Macartney and Staunton each with a cup of wine with his own hands. Later, as the embassy journeyed south, he sent a box of milk cakes to wish them a safe journey. ${ }^{56}$ Throughout the embassy the quantities of food provided to Macartney's retinue were so large that the English sometimes had to decline, or to give the food away to the Chinese sailors and transport workers. For an ambassador to be hosted by the receiving monarch was not part of contemporary European diplomacy, but it had until recently been the case in relations between European states and Russia with which Macartney was familiar having held a previous posting in St Petersburg. He protested at first that the embassy was willing to pay for its own provisions but then accepted at the Qing officials' insistence. ${ }^{57}$ His comptroller John Barrow included in his published account of the embassy a comparison between the sums that the Chinese spent on hosting the embassy and the total cost of the British gifts. To do this he made enquiries with one of the officials charged with conducting the embassy. Based on the figures he received he calculated that the embassy cost the Chinese 519,000 taels or approximately $£ 173,000$, not including the gifts provided from the palace

\footnotetext{
53 Zhang, Qingdai chaoqin, pp. 284-5; He, Qingdai gongwu, pp. 11-12, 23-30, 184-5.

${ }^{54}$ Yingshi Magaerni, p. 56; E.T. Backhouse and J.O.P Bland, Annals and Memoires of the Court in Peking (London: W. Heinemann, 1914), pp. 324-5. The terms involved are: 瞮 ji (to give), 萬國來王. 種種貴重之物 wanguo lai wang, zhongzhong guizhong zhi wu (the myriad countries come to the king with many different valuable items), 凡外藩使臣到京 fan waiwan shichen dao jing (all the outer barbarians send envoys to the capital), 貢使 gongshi (envoy bringing gifts).

${ }^{55}$ He, Qingdai gongwu, p. 3; Qinding da Qing huidian, juan 56, p. 1. See also A. Chau, "Household Sovereignty and Religious Subjectification: China and the Christian West Compared” Studies in Church History l (2014), pp. 492-504; Hevia, Cherishing Men from Afar.

${ }^{56}$ Macartney, Embassy to China, pp. 71, 123; Anderson, Narrative of the Embassy, p. 78; Yingshi Magaerni, p. 443.

${ }^{57}$ Hüttner, Voyage a la Chine, p. 24.
} 
storehouses. By comparison he reckoned that the total cost to the British, including the gifts but not the cost to the navy of providing the ship, was $£ 80,000 .^{58}$ A display of generosity on this scale was undoubtedly a performance of superiority by the Qing emperor, but the metaphor of hosting is very different from the metaphor of taxation implied by the English term tribute.

Another important concept through which gifts were understood and interpreted by the Chinese was that of tan 領 which refers to feelings of greed for wealth or women that lead to the creation of unacceptable relationships. Tan is usually translated as corruption, but often refers to extortion, and, unlike the English term bribe, it is an accusation made against the recipient of gifts rather than the giver. Eighteenth-century Qing officials were the representatives of a powerful and expansive state which provided them with opportunities for the extortion of huge wealth. Similar issues over gifts had emerged from the expansion of British power in India: Macartney had been sent as Governor to Madras in 1781 to combat the scandals in the East India Company and he saw his incorruptibility at that time as a reason why he was chosen as ambassador to China. ${ }^{59}$ In London the trial of Warren Hastings, the former governor of Bengal, on charges that focussed closely on the distinction between presents and bribes, was dragging on throughout the time that the embassy was in China, where the last years of the eighteenth century were also characterised by a crescendo of accusations and political scandals related to gift giving. However, unlike the British distinctions made over the objects (presents, bribes, tributes), the Chinese focus was on the giver and his corrupt desires (tan). ${ }^{60}$

Macartney in Beijing heard rumours of accusations against Heshen, then the most powerful official in the empire, which would lead to his execution on the emperor's death in 1796 in what became one of the greatest corruption scandals in Chinese history. ${ }^{61}$ His account also mentions two men in the trade who had fallen as a result of such accusations: one whose confiscated mansion in Beijing was used to house the embassy, and another who was brought out of prison to consult on how to handle the embassy. ${ }^{62}$ The house may well have been that of Li Shiyao, former Governor General of Guangdong and Guangxi as well as Inspector of the Guangdong Customs, who had been renowned for the quality and quantity of his gifts to the emperor which included items such as Gobelin tapestries from Europe. Li had fallen from power in 1780 after accusations related to the gifts he himself had accepted from his subordinates. ${ }^{63}$ The concern with tan also affected the way that the emperor responded to gifts from the British, since it was considered proper for the recipient to reject a proportion of what was offered. The Qianlong emperor rejected many of the gifts presented to him by Li Shiyao, though he accepted many more. He would do the

\footnotetext{
58 John Barrow, Travels in China: Containing Descriptions, Observations, and Comparisons, Made and Collected in the course of a Short Residence at the Imperial Palace of Yuen-min-yuen, and on a subsequent journey through the country from Pekin to Canton. (London: T. Cadell \& W. Davies, 1804), pp. 605-8.

${ }_{59}$ IOR/G/12/91, pp. 129, 143, Macartney to Dundas, 4 June 1792.

${ }^{60}$ N.E. Park, “Corruption in Eighteenth-Century China” Journal of Asian Studies lvi (1997), pp. 9671005.

${ }^{61} \mathrm{IOR} / \mathrm{G} / 12 / 92$, p 69, Macartney to Dundas 9 November 1793.

${ }^{62}$ Macartney, Embassy to China, p. 142; Barrow, Travels in China, p. 104.

${ }^{63}$ Dong Jianzhong, “Li Shiyao jingong jianlun” 李侍堯進貢簡論 [A brief discussion of Li Shiyao’s tribute gifts] Qingshi yanjiu 清史研究 [Qing history research] v (2006), pp. 111-6; Ashmolean Museum, Oxford, WA1901.1, Le combat d'Animaux.
} 
same with the British gifts. ${ }^{64}$ As was the case for the British, the domestic politics of gift giving in China also affected both the giving and receiving of the embassy's gifts.

The reception of gifts during the embassy also reflected the way in which gifts were being used as part of the negotiations. Both the British and the Qing presented gifts that they saw as displaying the sources of their wealth, and power and the ideologies that underpinned these. But, whereas gifts that were familiar trade items were readily interpreted by the recipients in terms of their trade value, and while both sides presented gifts intended to inform the other, neither chose to try and understand the more complex claims that the other was making.

For the British the problems focussed on the scientific instruments that they had brought and how to use them to explain the links they perceived between natural philosophy, free trade, wealth and manufacturing. On the embassy's arrival in China, officials requested a list of the gifts. The East India Company had left how and when to give their gifts and to whom to Macartney's discretion, so the British were neither ready nor particularly willing to supply such a list. ${ }^{65}$ For the Chinese, on the other hand, the ettiquette of gift giving required that the emperor should be presented with a list of the items that he was receiving to look over and enjoy. Moreover a gift list of this sort was expected to conform to a format in which the quantity of each item was listed with very little space for description. When the English did eventually provide a list, it did not fit with Chinese expectations of what such a list should look like nor did it reflect the market value of the gifts. ${ }^{66}$ Instead it was a lengthy text that attempted to fix the meaning of the major items that the British had presented. It appears to have been compiled by Staunton, who was an enthusiast for the new scientific and technological discoveries of the age. It is headed by the planetarium along with the Herschel reflector telescope, then the orrery, globes, a combined clock and barometer, an air pump, a set of mechanical powers and a pair of mechanical chairs which would illustrate the powers. Then come several items that might be thought of as illustrations of British achievements: examples of Wedgewood porcelain, the burning lens, and a set of prints and illustrated books. Down at the bottom of the list are the more conventional and costly diplomatic offerings: the glass chandeliers, painted wall coverings, a saddle and harness, the two carriages, along with the weapons and model warship. Finally, right at the end of the list is an entry for examples of British manufactures including the woollen textiles. ${ }^{67}$

The problems faced by the European missionaries at the court who were required to produce a translation of this document are perhaps best illustrated by how they dealt with the description of the first item: the planetarium (fig. 1). The Chinese version that the missionaries produced is much shorter than the English original and cuts a considerable amount of the technical detail, such as the explanation that the planetarium could depict the motions of Jupiter 'which has four moons constantly moving about it, as well as Belts around it, and also of the planet Saturn with a Ring

\footnotetext{
${ }^{64}$ Aeneas Anderson, An Accurate Account of Lord Macartney’s Embassy to China (London: Vernor \& Hood, 1797), p. 95; Barrow, Travels in China, p. 312.

${ }^{65}$ IOR/G/12/91, p. 192, Dundas to Macartney, 8 Sept. 1792; Staunton, Authentic Account, I. 490-1; Yingshi Magaerni, p. 356.

${ }^{66}$ Yingshi Magaerni, p. 356; Dong, “Qing Qianlong chao wanggong dachen”.

${ }^{67}$ IOR/G/12/92, 155-68, Catalogue of presents sent by His Britannic Majesty. (Versions in Staunton Authentic Account I. 490-8 and Cranmer-Byng and Levere 523-5 are abridged). For Staunton's interests see his son's diary: George Thomas Staunton, Diary 1791, MS. Duke University Library.
} 
and five moons regularly going round it. ${ }^{68}$ It also omits much of the flattery, as where the English text claims of the planetarium that 'for above a thousand Years it will be a Monument of the respect in which the virtues of his Imperial Majesty are held in the remotest parts of the World. ${ }^{69}$ Since the missionaries worked as astronomers at court they presumably could have translated the phrases about the moons of Jupiter and belts of Saturn. It is possible that they deliberately manipulated the descriptions out of national hostility to the British, but it seems more likely that they were hampered by different expectations of genre. Their compromise was to reduce the length of the text, and even so their translation was presented to the emperor with many apologies. Not only did the flattery about the relationship of the emperor's virtue to the clockwork vision of the cosmos make little sense in a Chinese cultural context, but the genre of a gift list simply did not make it a good place to try and convey elaborate ideas about the meaning of the gifts. The emperor's private response to the British gift list, even in its reduced form, was to comment that it was probably just a reflection of the conventionally boastful barbarian character. ${ }^{70}$

This is not to say that the scientific gifts were unfamiliar or uninteresting to the Qianlong emperor: for the most part they were very similar to other items in his collections. The first set of gifts were presented in Rehe, a palace complex in the hills beyond the Great Wall where the emperor customarily received envoys from central Asia, and was to receive Macartney as part of his birthday celebrations. The British took with them the most portable of the gifts: the prints, carpets, sadlery, guns, swords, bolts of English woollen cloth and Irish textiles (Macartney was eager to promote Irish manufactures), and two telescopes. ${ }^{71}$ It appears that the emperor looked at these gifts with care, since he sent a set of prints of portraits of the English nobility back to Beijing to have the names and titles translated into Manchu and Chinese. ${ }^{72}$ Meanwhile Macartney and his retinue were taken to view the gardens of the imperial palace. Only then did they realise the full extent of the emperor's collection of European exotica. The Qianlong emperor received several hundred European items every year as gifts from the officials in charge of the trade in Guangdong. ${ }^{73}$ In the pavilions at Rehe Macartney and his retinue found spheres, orreries, clocks and musical automata that were far finer than the gifts they had brought. ${ }^{74}$ The reflecting telescope and burning lens that Macartney had purchased at such cost in Macao had been available from the East India Company merchants there precisely because there was a market for this kind of object in China. The telescope was only one of the London-made telescopes to reach the court in this period. ${ }^{75}$ The emperor had inherited at least a part of his grandfather the Kangxi emperor's interest in the workings behind these objects and would occasionally ask to have the science

\footnotetext{
${ }^{68}$ IOR/G/12/92, p. 157, Catalogue of presents sent by His Britannic Majesty; Yingshi Magaerni, pp. 121-2, 356.

69 Ibid.

${ }^{70}$ Yingshi Magaerni, p. 40.

${ }^{71}$ These gifts are listed in Yingshi Magaerni, p. 563; Anderson, Narrative of the Embassy, p. 144.

${ }^{72}$ Barrow, Travels in China, p. 114.

${ }^{73} \mathrm{He}$, Qingdai gongwu, p. 136.

${ }^{74}$ Macartney, Embassy to China, p. 125. Many items made in London and dating from the years before the embassy survive in the collections of the Palace Museum in Beijing. C. Pagani, Eastern

Magnificence and European Ingenuity: Clocks of Late Imperial China (Ann Arbor: University of Michigan Press, 2001), p. 62

${ }^{75}$ Gugong bowuyuan [Palace Museum] website (www.dpm.org.cn): Orange shellac brass telescope, Gilbert \& Wright, London (橙漆皮铜镀金望远镜); Wooden frame hexagonal astronomical telescope, Herschel (木制六棱形天文望远镜).
} 
explained. Mostly, however, they were given and displayed as valuable and exotic amusements. $^{76}$

Once the British had seen the emperor's collection they became very cautious about presenting the less valuable objects that they had brought with them. Many of the mathematical and philosophical instruments purchased in London were never given to the Chinese. (Some were never even unpacked.) A part of these were returned to the East India Company and sold off in Guangzhou. Others, including the chemical experiments and the model steam engine, were given to James Dinwiddie who had come with the embassy as its mechanic and then set off to India to make his fortune as a scientific demonstrator. ${ }^{77}$ With the gift list abbreviated, conventional diplomatic gifts presented to the emperor in Rehe, and some of the scientific gifts remaining in their boxes, Staunton's vision of the embassy as an explication of British natural philosophy was largely lost.

Meanwhile, it was just as difficult to convey to the British the meanings of the Qianlong emperor's gifts. Johann Christian Hüttner, who saw the Chinese gifts displayed in the gardens at Rehe, wrote, 'One could not help reflecting on the comparison between the lanterns and the precious mathematical instruments, between the silk purses and fans and the highly polished tools and other British manufactures of great price. ${ }^{78}$ This was somewhat disingenuous since the British were well aware that the tea, silk and porcelain they were given was valuable. But the Chinese gifts too were also intended to display the sources of state power. From the cloisonné and jade objects that headed the list to the boxes of Tibetan sugar that ended it they displayed China's technological skills, but also the Qing dynasty's links to China's ancient history, and its recent military victories.

The original list of Chinese gifts to be given to George III that is preserved in the Qing archives is headed by a sandalwood and cloisonné sculpture of the Eight Immortals Crossing the Ocean on a dragon boat. ${ }^{79}$ This refers to the story of the eight Daoist immortals who travelled to bring their congratulations to the Queen Mother of the West on her birthday. Since the British had come by sea to attend the emperor's eightieth birthday the choice of scene was auspicious, complimentary to both the emperor and the British, and appropriate to the occasion. Similar themes had been depicted in the spectacular opera with which Macartney was entertained at the palace. This featured the God of Literature leading a group of star spirits across the sea to congratulate the emperor and the special effects ended with a whale that spouted water from its mouth in front of the emperor. ${ }^{80}$ It seems that the sculpture was never presented as it does not appear in a later published version of the Qing gift list or in the English version (apparently made by someone looking at the objects as the boxes were opened) where it is replaced by 'an instrument made of the wood called Todtau,' which probably refers to a sandalwood sceptre, an item which would maintain

\footnotetext{
${ }^{76}$ Dong, “Chuanjiaoshi jingong”.

${ }^{77}$ Cornell, Manuscripts relating to the Macartney mission vol. 8 doc. 354 Presents delivered and the remainder how disposed of; William Jardine Proudfoot, Biographical Memoir of James Dinwiddie, LL.D. Astronomer in the British Embassy to China, 1792, '3, '4: Afterwards Professor of Natural Philosophy in the College of Fort William Bengal (Liverpool: Edward Howell, 1868), pp. 87, 112; Pritchard, "Instructions of the East India Company”, pp. 393, 501-2; Macartney, Embassy to China, p. 125.

${ }^{78}$ Hüttner, Voyage a la Chine, pp. 89-90.

${ }^{79}$ Yingshi Magaerni, p. 96.

${ }^{80}$ Ye, "Ascendant Peace in the Four Seas."
} 
the auspicious theme and the link with British trade but was far less impressive. ${ }^{81}$ What is clear, however, is that the carefully selected meanings of the opera were lost on Macartney, who tried to make sense of it but came to the conclusion that it was about the marriage of Ocean and Earth. ${ }^{82}$ It is unlikely that he would have been any more successful at interpreting the sculpture.

The next items on the Chinese list were a series of jade urns, goblets, jars and bowls. Jade not only had an ancient history in China, but was also one of the characteristic products of the new province of Xinjiang, the furthest extent of the emperor's domains as the result of a massive recent military campaign against the Zunghars. The emperor was a connoisseur of jade: his collected works for this period are full of poems on particular jade pieces, often referencing the production of jade in the newly conquered territories and comparing these new pieces to those of ancient China. ${ }^{83}$ The British, on the other hand, were not familiar with jade and did not know where it came from. Mostly they defined it as a kind of agate. ${ }^{84}$ Staunton describes the white jade sceptre presented to George III as 'a gem, or precious stone, as it was called by the Chinese, and accounted by them of high value. ${ }^{85}$ The English version of the gift list simply transliterates, describing the jades as 'the stone yu. ${ }^{86}$ Barrow suggested that future embassies should take Derbyshire spar as a gift to the Chinese. ${ }^{87}$ Using Derbyshire spar to make decorative objects was newly fashionable in eighteenth-century England, but its value was in no way comparable to that of jade in China.

The Chinese gift list also records that 'On the day of the theatricals the king was presented with a book of paintings in the emperor's hand. It was stored in an inlaid sandalwood box which contained ten Han dynasty jade curios.' ${ }^{88}$ The Qianlong emperor enjoyed arranging and displaying precious items from his collection in these curio boxes, which had much in common with European cabinets of curiosities. As in this case, they often included items which linked his own rulership with China's ancient past. Here the Han dynasty (206 BC - 220 AD) jade pieces were matched with a book in his own calligraphy. ${ }^{89}$ The emperor made a speech to explain the meaning of this gift when he presented it to Macartney. One of the British couriers, who said he had asked the interpreter to recall the speech, recorded it as follows:

Deliver this casket to the King your master, with your own hand and tell him, though the present may appear small, it is, in my estimation, the most valuable that I can give, or my empire can furnish; for it has been transmitted to me through a long line of my predecessors, and is the last token of affection which I had reserved to bequeath to my son and successor; as a tablet of the virtues of my ancestors, which he had only to peruse, as I should hope, to inspire him with the noble resolution to follow such bright examples; and as they had done,

\footnotetext{
${ }^{81}$ Qinding da Qing huidian shili, juan 507, p. 25; IOR/G/12/92, p. 317, Catalogue of the Emperor of China's Presents.

${ }^{82}$ Macartney, Embassy to China, p. 137.

${ }^{83}$ Qing Gaozong (Qianlong) yuzhi shiwen quanji 清高宗(乾隆)御製詩文全集 [The collected poetry and prose of Qing Gaozong (Qianlong)] (Beijing, 1993), vol. 9. juan 81 p. 7-19.

${ }^{84}$ Macartney, Embassy to China, p. 122.

${ }^{85}$ Staunton, Authentic Account, II. 232.

${ }^{86}$ IOR/G/12/92, pp. 317, 327, Catalogue of the Emperor of China's presents.

${ }^{87}$ Barrow, Travels in China, p. 343.

${ }^{88}$ Yingshi Magaerni, p. 101.

${ }^{89}$ Yu Peijin 余佩瑾. “Pinwei yu yitu - Qing Qianlong ‘Jiqiongzao”” 品味與意圖一清乾隆集瓊藻

[Taste and meaning - the Collection of Beatiful and Elegant Objects from the Qianlong era of the Qing] Gugong wenwu yuekan 故宮文物月刊 ccxciv (2007), pp. 16-26.
} 
to make it the grand object of his life to exalt the honour of the Imperial throne, and advance the happiness and prosperity of his people. ${ }^{90}$

The English version of the speech is garbled, but it does suggest that the curio box sent to George III was a very personal gift and that it was intended to draw a link between China's ancient history and its current ruler. However, in his diary Macartney described the emperor's gift as 'a little box of old japan in the bottom of which were some pieces of agate and other stones much valued by the Chinese and Tartars, and at the top a small book written and painted by his own hand. ${ }^{91}$ Later the Times in London claimed, wildly inaccurately, that the gift was an epic poem by the Emperor addressed to the king in 'a black wood carved box, of no great value, but as an antique - to which character it has a just claim, having been 2000 years in possession of the Imperial family of China.' 92 Staunton's published account presented the gift as an example of the emperor's good governance that gave him the leisure to cultivate the polite arts and write poetry. ${ }^{93}$ Both the compliment and the boast intended by the curio box were lost to the English recipients, just as those contained in the description of the planetarium had been lost to the Chinese.

This was not the only gift to boast of Qing power. Behind the diplomacy and the gifts lay the trade and taxation issues that the British hoped to negotiate, and behind the trade negotiations lay the military might of the two states. Much previous scholarship has emphasized Macartney's negative assessments of Qing weaponry, but the embassy was taking place at the end of more than a century of Qing military expansion. Gifts of jade that headed the Chinese gift list were a reminder of the conquest of Xinjiang as were the pictures of Qing battles. The final item on the list was a pair of boxes of Tibetan sugar. This was one of the items presented to the emperor earlier in the year, along with elephants, peacocks, guns and swords, by the Gurkhas when they withdrew their army from Tibet after a major Qing campaign against them. ${ }^{94}$ As in 1760, when the emperor had sent ancient Chinese coins found in Xinjiang as a gift to Catherine the Great of Russia, the gift of sugar to the British referenced Qing control in an area that the court was at least hazily aware might have connections with British territory. ${ }^{95}$ However, although Macartney was aware of Qing officials' interest in British connections with the Gurkhas he paid no attention to the Tibetan origins of the gift of candy.

Chinese interest in the British gifts also focussed on those with military relevance. The embassy had been provided with a large house in Beijing and several of the gifts that were not presented at Rehe, including the cannon, were put on display there. So many people came to look that the British were dismayed and decided to

\footnotetext{
${ }^{90}$ Anderson, Narrative of the Embassy, p. 154. A similar surviving curio box from the emperor's collection contains a set of twelve jade figurines representing the animals of the zodiac and thus the ancient past and a book of poems written out by one of the emperor’s sons. Zhang Lirui 張麗瑞, “Qing Qianlong zitan ‘wannian jiazi’ duobaohe” 清乾隆紫檀萬年甲子多寶盒 [The Ten Thousand Year Cycle sandalwood curio box from the Qing Qianlong emperor] Gugong wenwu yuekan 故宮文物月刊 cccxxiii (2010), pp. 82-6.

${ }^{91}$ Macartney, Embassy to China, p. 137.

92 Times 29 Sept. 1794, p. 3.

${ }^{93}$ Staunton, Authentic Account, II. 266.

${ }^{94}$ Yingshi Magaerni, p. 98; Qing Gaozong (Qianlong) yuzhi shiwen quanji vol 9 juan 77 p. 52; Mosca, From Frontier Policy to Foreign Policy, pp. 135-54.

${ }^{95}$ Yu-chih Lai, “Coining Territory: Emperor Qianlong’s Gift to Catherine the Great” paper presented at the Association of Asian Studies, Toronto, March 16-19 2017.
} 
impose restrictions. ${ }^{96}$ Meanwhile, the gifts that Qing officials regarded as most impressive, were displayed in the Yuanmingyuan outside Beijing. This was one of the emperor's main residences whose gardens included Italianate palaces and water gardens designed by the European Jesuits. The planetarium, orrery, globes, chandeliers, and the clock and barometer on their satinwood stands decorated with porcelain were all set out in the main audience hall used by the emperor to receive senior officials and visiting envoys in a complex that also housed some of the offices of the emperor's personal administration. Later the air pump, six cannon, mechanical chairs, burning lens, carriages, mechanical powers, and model warship were added though some were placed in another lesser hall. ${ }^{97}$ The Yuanmingyuan housed various offices of state, and the gifts there also drew considerable numbers of visitors, including the princes of the imperial household. After the emperor had returned from Rehe, he came in person to inspect them. It was on this occasion that he selected which gifts he would keep and rejected as suitable only for children two camera obscura, which were very similar to the peepboxes showing European scenes that were already popular marketplace attractions in China at this time. This very proper display of his absence of greed in a Chinese context, was deeply disappointing to the British who explained it as a result of a lack of interest in science. ${ }^{98}$

The gifts that drew most attention were the model warship, cannon, guns, pistols and swords. As Joanna Waley Cohen has noted, the Qianlong emperor like his predecessors had a longstanding interest in European military technology. ${ }^{99}$ On this occasion he was very much aware that British negotiating demands were backed up by five armed ships waiting off Ningbo where the British hoped to get an island as a commercial base. ${ }^{100}$ When the list of gifts presented by the English was translated into Chinese most of the entries were drastically abbreviated. The one exception was the description of the scale model of HMS Royal Sovereign, one of the largest and best armed ships in the British navy. Here the entire gist of the English text was maintained, though the translation also inaccurately suggested that this was a model of the ship in which the British had come to China and that was waiting for them off the coast. ${ }^{101}$ The result was to make the model ship appear far more important among the other gifts than it had been in the original English. The translation appears to have shaped, or at least accurately predicted, the emperor's interests, since when he viewed the presents in the Yuanmingyuan it was the ship that attracted his attention. He asked such detailed and technical questions about it that the interpreter was unable to

\footnotetext{
${ }^{96}$ Macartney, Embassy to China, pp. 104-5; Anderson, Narrative of the Embassy, pp. 118-9; Yingshi Magaerni, p. 563.

97 This was the Zhengda guangming dian 正大光明殿. Yingshi Magaerni, p. 563; William Jardine Proudfoot, “Barrow's Travels in China”: An Investigation (London: George Philip and Son, 1861), pp. 36-9; Macartney, Embassy to China, pp. 103-4; L.M. Li “The Garden of Perfect Brightness: The Yuanmingyuan as Imperial Paradise (1700-1860)” MIT Visualizing Cultures (visualizingcultures.mit.edu); A. Gerritsen and S. McDowall, "Material Culture and the Other: European Encounters with Chinese Porcelain c 1650-1800” Journal of World History xxiii (2012), p. 110.

${ }^{98}$ Anderson, Narrative of the Embassy, p. 176; Barrow, Travels in China, pp. 109-113, 121, 312; Kristina Kleughten, “Peepboxes, Society, and Visuality in Early Modern China,” Art History xxxviii (2015), pp. 762-777.

${ }^{99}$ J. Waley-Cohen, “China and Western Technology in the Late Eighteenth Century” American Historical Review xcviii (1993), pp. 1525-44.

${ }^{100}$ Yingshi Magaerni, pp. 171-2, 393-7, 402-4, 434-5.

${ }^{101}$ IOR/G/12/92, p. 167, Catalogue of presents sent by His Britannic Majesty; Yingshi Magaerni, p. 124.
} 
answer. ${ }^{102}$ Moreover, the ship was included in the list of gifts in the palace the following year, although it was well below the value of most of the articles individually listed by that point. ${ }^{103}$

This was not the only sign of interest in the military items. The emperor accepted an offer by the British to fire the cannon they had brought, and which were displayed in their Beijing residence, in his officials' presence. ${ }^{104}$ Firearms were a conventional diplomatic gift and were regularly presented to Qing emperors by Europeans but also by other foreign states: the Portuguese had presented flintlock guns and pistols in in 1753 and the Gurkhas too had presented European guns. ${ }^{105}$ The British cannon and the other firearms were listed in greater detail than other items in the palace records, and one of the hunting guns (fig 2) now held in the National Palace Museum maintains its original leather label in Chinese, Manchu, Mongol and Tibetan saying 'One self-firing [i.e. flintlock] gun presented in the $8^{\text {th }}$ month of the $58^{\text {th }}$ year [of the Qianlong emperor],' showing that not only its provenance but also its firing mechanism mattered to the Chinese. ${ }^{106}$ Chinese visitors to the embassy's residence in Beijing were also enthusiastic about the steel swords manufactured by Thomas Gill of Birmingham (fig. 6). Swords had long been a common collectors' item and the emperor himself had a large collection. Now Qing military officers came to examine the English blades and were delighted to receive one as a personal gift. ${ }^{107}$ In one of the very few mentions of the embassy by a member of the Chinese literati, Zhao Shenzhen recalls the impressive flexibility of the steel blades. ${ }^{108}$ Other gifts were interpreted from a military standpoint. When James Dinwiddie demonstrated Parker's great lens to Heshen, the minister not only amused himself by lighting his pipe at it, but also asked if it could be used to set fire to an enemy town. ${ }^{109}$ Dinwiddie was shocked at what seemed to him a flippant attitude, but this was not the first ‘burning lens' that a Qing emperor had received from Europeans. ${ }^{110}$

As the accounts of officials receiving British swords suggest, gifts given to individuals were also an essential part of the embassy. When the East India Company initially purchased the gifts in London, by no means all were intended for the emperor. Before he left England Macartney proposed to Dundas that he intended to be candid and liberal rather than indulging in corruption and intrigue since the Chinese had 'refined sentiments of virtue and honor.' ${ }^{111}$ This did not mean that he did not present valuable gifts to Chinese officials, but rather that he offered them objects rather than cash. The Qianlong emperor had no such qualms about British notions of honour and presented silver specie as well as large numbers of valuable gifts to individuals. ${ }^{112}$ At

\footnotetext{
102 Staunton, Authentic Account, II. 324.

103 Yingshi Magaerni, p. 204.

${ }^{104}$ Anderson, Narrative of the Embassy, pp. 119, 171; Macartney, Embassy to China, pp. 90.

${ }^{105}$ Qinding da Qing huidian shili, juan 503, p. 18; He, Qingdai gongwu, pp. 240-3, 389.

${ }^{106}$ Yingshi Magaerni, p. 563; Gugong bowuyuan (National Palace Museum) Beijing, Self-firing gun presented by Macartney (马戛尔尼进自来火鸟枪) http://www.dpm.org.cn/shtml/117/@/6112.html; He, Qingdai gongwu, p. 479.

${ }^{107}$ Barrow, Travels in China, p. 112-3; Cornell, Manuscripts relating to the Macartney mission vol. 8 doc. 349 List of presents delivered; C. Clunas, Empire of Great Brightness: Visual and Material Cultures of Ming China, 1368-1644 (London: Reaktion Books, 2007), p. 177.

108 Zhao Shenzhen 趙慎畛. Yu chao za shi 榆巢雜識 [Miscellaneous notes from the elm tree ], ed. Xu Huaibao 徐懷寶 (Beijing: Zhonghua shuju, 2001), p. 89.

109 Proudfoot, “Barrow's Travels in China”, p. 40.

${ }^{110} \mathrm{He}$, Qingdai gongwu, p. 468.

${ }^{111} \mathrm{IOR} / \mathrm{G} / 12 / 91$, p 27, Macartney to Dundas, 4 Jan. 1792.

112 Yingshi Magaerni, pp. 101-6, 110-1, 134-7; IOR/G/12/92, pp. 332-48, Catalogue of the Emperor of China's presents; Barrow, Travels in China, p. 121; Anderson, Narrative of the Embassy, p. 175.
} 
his formal audience with the ambassador he presented a white jade sceptre to Macartney and a slightly less valuable but still impressive green one to George Leonard Staunton (fig 7). ${ }^{113}$ Later, during the negotiations that were carried on during the embassy's journey south, the emperor sent a piece of his own calligraphy as a personal gift to Macartney (as well as another for the king) to convince him of his willingness to deal with the English trading demands. ${ }^{114}$

Both the Chinese and the British were conscious that such personal gifts given to win allegiance were problematic for the state. Macartney responded to these anxieties by playing down the jade sceptre, writing that 'to me it does not appear in itself to be of any great value.' ${ }^{115}$ (This was true from a British perspective, when the more valuable sceptre presented to George III was sold in London in 1819 it fetched a mere $£ 1313 s) .{ }^{116}$ Qing officials, meanwhile, negotiated over what to accept from Macartney, since there was a ban on provincial officials accepting gifts from foreign countries. ${ }^{117}$ The two lower ranking officials who accompanied the embassy throughout its time in China solicited a gift, when offered cash refused, but accepted swords, watches, woollen cloth, pocket books and spectacles. ${ }^{118}$ Songyun, the specialist in dealing with the Russians who acted as the embassy's handler during the first part of the journey south, accepted 20 bottles of European wine. He told the emperor of the gift and that he had said to the English that he could not have accepted other gifts. ${ }^{119}$ Individual presents were only unproblematic when the value was relatively low and the gifts could be reciprocated as when Qiling'a, the governor of Jiangxi, paid a visit to the embassy as it passed through his province: he gave Macartney tea, teacups, beads (presumably a Buddhist rosary an item widely carried by the Chinese elite), and silk, and received in return a pair of pearl watches, hardware, knives, scissors and brandy. ${ }^{120}$ As this suggests, at every stage of the embassy the high value of the gifts was understood as to the advantage of the side that gave them and potentially problematic for the recipients.

In the years that followed the embassy most of the gifts disappeared into vast royal collections of similar objects. The British gifts that survived did so as valuable exotica, most of them boxed, wrapped up, and stored away in the Qing emperor's private collection, but with the textiles circulating as part of a broader economy of imperial gifts. The Chinese gifts to George III entered Queen Charlotte's collection, from which they were sold in a great auction after her death. The teas were presumably drunk, the textiles made into clothing, and smaller porcelain items were used and broken. ${ }^{121}$ The items that survived nearly all lost their link with the embassy

\footnotetext{
${ }^{113}$ Yingshi Magaerni, p. 2; Anderson, Narrative of the Embassy, p. 148; Macartney, Embassy to China, pp. 122-3.

${ }^{114}$ Yingshi Magaerni, p. 188; IOR/G/12/92, p. 109, Macartney to Dundas, 9 Nov. 1793.

115 Macartney, Embassy to China, p. 122.

${ }^{116}$ London, Christies Auction House, Catalogue of the Remaining Part of a Valuable Collection of Curiosities comprising Carvings in Ivory, Trinkets, Coins, Porcelains and Furniture, and Paintings by Van Huysam and Gainsborough which will be Sold by Auction by Mr Christie at his Great Room, Pall Mall on Monday 24 May 1819 and Two Following Days (London: G. Smeeton, 1819) (auctioneer’s annotated copy), Day 1 item 54.

${ }^{117}$ Qinding da Qing huidian shili, juan 511, pp. 1-2.

${ }^{118}$ Macartney, Embassy to China, pp. 97-98; Cornell, Manuscripts relating to the Macartney mission vol. 8 doc. 349 List of presents delivered.

${ }^{119}$ Yingshi Magaerni, pp. 460-1; Macartney, Embassy to China, pp. 178

${ }^{120}$ Macartney, Embassy to China, pp. 188.

${ }^{121}$ Ayers, Chinese and Japanese Works, II. 246, III.
} 
and can now only be identified by the painstaking and unreliable process of matching surviving objects to brief descriptions in the original gift lists.

Shortly after the embassy ended, the emperor sent some of the British woollen textiles on from the palace storehouses as gifts to his high officials. Letters of thanks survive from two provincial governors. The governor of Jiangxi wrote about the emperor's kindness and concern for him in sending him cloth that would keep him warm in the northern snow and bitter winds. The governor of Huguang emphasized the value of a gift brought by the British who had come from so far across the sea. ${ }^{122}$ The literature on Britain's China trade in this period tends to emphasize the difficulty Chinese merchants had disposing of British woollen cloth. Certainly woollens were not as profitable as tea, and Chinese merchants took them in order to get the tea trade, but the reception of them in the embassy shows that high quality woollens were indeed valued. Barrow, summing up the general reception of the gifts, recommended that future embassies should take as gifts 'good quality broadcloth and kerseymeres. ${ }^{123}$

Some of the largest and most impressive British gifts remained on display in the imperial palaces. The elaborate set of satin wood tables designed by Benjamin Vulliamy with marble tops and mirrors to display a barometer in the form of an armillary sphere and a clock topped by a porcelain figure of a woman leaning on a pedestal and looking at the moon had been particularly admired by some of the princes when it was on display in the Yuanmingyuan and evidently appealed to the emperor himself. It was moved from the Yuanmingyuan to the Palace of Tranquil Longevity (Ningshougong) which he had built as a retirement retreat for himself in the Forbidden City. The planetarium, orrery and globes were put on display in the Observatory of Distant Oceans (Yuanyingguan) and its surrounding buildings in the European-style section of the Yuanmingyuan. The chandeliers, barometers, model ship and a pair of Merlin's mechanical chairs, as well as some of the porcelain, prints, and William Hamilton's Campi Phlegreae, with its striking illustrations of the explosions of Mount Vesuvius, became part of the emperor's collection of Western exotica displayed in the buildings around the fountains in this garden. Other items were carefully inventoried, tagged, provided with fine wooden boxes, and entered the palace store rooms. ${ }^{124}$ Given the vast quantities of items with which the Qianlong emperor was presented over the years this was far from a surprising outcome.

The two hugely expensive summer and winter carriages and the most impressive weaponry were put out on display. It was impossible for Chinese who saw the carriages to imagine how the emperor could be seated below a coachman, so the carriages were never publicly used as the British had hoped. Neverthless, each was paired up with one of the two howitzer cannons: one pair was displayed in the Yuanmingyuan and the other in the Garden of Tranquillity and Pleasure (Jingyiyuan), part of another palace complex in the Western Hills. ${ }^{125}$ In 1860 when the Yuanmingyuan was sacked by British troops the carriages and howitzers were found there, together and in good condition, leading to claims that they had never been

\footnotetext{
122 Yingshi Magaerni, pp. 451, 484, 662; Barrow, Travels in China, p. 528.

${ }^{123}$ Barrow, Travels in China, p. 343.

${ }^{124}$ Yingshi Magaerni, p. 204; Macartney, Embassy to China, pp. 103-4; Gerritsen and McDowall,

"Material Culture and the Other”; Li, “The Garden of Perfect Brightness”; IOR/G/12/91 p. 285,

Records of sundry articles purchased by Francis Baring.

${ }^{125}$ Barrow, Auto-biographical Memoir, p. 103; Yingshi Magaerni, p. 204.
} 
used. ${ }^{126}$ However, if the British accounts are accurate in saying that both carriages were found in the Yuanmingyuan, it appears that one of the carriage and howitzer pairs was sufficiently valued for it to be moved back there at some point.

A silk tapestry probably commissioned for the court after the completion of the embassy suggests how the gifts were remembered (fig. 8). In the top right hand corner of the tapestry is the poem by the emperor which speaks of the gifts as trifles. However, although this makes it clear that the embassy is Macartney's the British are depicted in seventeenth-century costumes. The gifts are huge astronomical instruments, not in the least like the planetarium that was actually presented. Instead the objects were drawn from published illustrations of items given to the emperor by the Jesuits earlier in the century. ${ }^{127}$ What matters here is the splendid gifts of astronomical and clockwork items that had long been part of the trade with Europe, and the exotic foreign people who bring the characteristic products of their country to the emperor.

The fate of the Chinese gifts in England was not dissimilar. As diplomatic gifts to the king many disappeared from public view into the private collection of the royal family, where they became particularly fine examples of a fashionable enthusiasm for oriental exotica. The items presented to George III entered Queen Charlotte's longstanding collection of oriental curiosities and porcelain. Some of these were used to decorate her home in Frogmore House. The lacquer cabinet and boxes presented by the emperor (figs 3 and 4) and can be seen in the bottom left hand corner of an illustration of one of the rooms (fig. 9). ${ }^{128}$ When the queen died in 1819 her personal property was left to her daughters and the majority of it was auctioned over several months. The catalogues for these sales include the vast majority of the items given by the Qianlong emperor and annotated copies held by Christies Auction House tell us who the purchasers were. Most items were sold to dealers and agents, but individual purchasers included the politician Lord Rolle, who bought a set of plates, and the society figure Major George Blaquiere who bid successfully for some of the bamboo furniture, paper and silk wall hangings, and several lengths of embroidered satin. Oriental items were seen as pretty and feminine and a number of women bought porcelain and fans: Lady Arden and Lady Sykes, the wives of wealthy members of parliament, and Mrs Coutts, from the well-known banking family, bought sets of plates and bowls, while Lady Harcourt a close friend of the deceased queen, bought four fans. ${ }^{129}$

The silk textiles were the most valuable of the emperor's gifts, just as they had been when they were given. The Chinese item that made the highest price was described as ' $8 \frac{1}{4}$ y yards of puce Chinese sattin, embroidered with dragons, symbols,

\footnotetext{
${ }^{126}$ D.F. Rennie, The British Arms in North China and Japan: Peking 1860, Kagoshima 1862 (London: John Murray, 1864), p. 166; Robert Swinhoe, Narrative of the North China Campaign of 1860 (London: Smith, Elder \& Co, 1861), p. 331; J.L. Hevia, “Loot's Fate: The Economy of Plunder and the Moral Life of Objects 'From the Summer Palace of the Emperor of China'” History and Anthropology vi (1994), pp. 319-45.

${ }^{127}$ B. Huang, "The Fabric of Occidentalism: The Macartney Embassy in a Qing Dynasty Tapestry.” Unpublished MS; Schaffer, "Instruments as Cargo”. Huang argues that Schaffer’s dating is unconvincing given the technical complexity of the work.

${ }^{128}$ Joseph Farington, The Diary of Joseph Farington (Kenneth Garlick and Angus Macintyre ed.) (New Haven: Yale University Press, 1979), III. 918-9; Roberts, George III and Queen Charlotte, p. 164. ${ }^{129}$ Christies, A Catalogue of the First Part of a Magnificent Collection of Oriental Curiosities and Porcelain etc etc which will be removed toMr Christie's Great Room, Pall Mall and will be sold by auction by Mr Christie on Friday, May 7, 1819, and Three Following Days (London: Christies, 1819); Christies, A Catalogue of the Remaining Part; Roberts, George III and Queen Charlotte, p. 385-6.
} 
and waved ornaments, in rich and variously coloured silks, and gold thread, being THE VEST of a CHINESE MANDARIN, not made up: also 3 pieces for the sleeves, richly embroidered on chocolate sattin' ${ }^{130}$ Together with two embroidered purses this sold for $£ 84$. Overall the Prince Regent paid £1,684 12s 41/2d for Chinese textiles and the tassels and fans that were sold with them. He may well also have been acting through Robert Fogg, a dealer who purchased additional lacquer, porcelain, papers and textiles. ${ }^{131}$

The gifts that expressed philosophical ideas made little impression on the purchasers from the London elite. William Beckford, a wealthy and eccentric recluse with a longstanding passion for collecting hardstones, attended the viewings of the Queen's collection and wrote 'I have seen the jade pieces, which I detest.' ${ }^{132}$ As a collector Beckford was well aware of jade (the term was derived from Portuguese, a language he spoke), but his preference was for a clear crystalline stone. He did, however, buy the jade sceptre and the curio box presented by the emperor. The curio box was listed as 'A box of rose-wood, on the side are ornaments of steatite in relief; within are specimens of different kinds of jad, and a Chinese treatise on plants.' ${ }^{\text {, }}$ The fact that the book was in the emperor's calligraphy had been forgotten, and the box and its contents sold for just $£ 22$ s. After the sale the box disappears, but the sceptre was displayed alongside a topaz vase by Cellini, an amber jewel cabinet made for a Bavarian princess, and other precious items in the Yellow Drawing Room at Fonthill Abbey, Beckford's vast new gothic fantasy building. ${ }^{134}$ Together the ten jade items in the sale (one more than the emperor had given) made a total of only a little over $£ 190$.

The later history of the Chinese and British gifts was remarkably similar. The Chinese lacquer boxes that remained in the British royal collection, and probably much of the porcelain as well, were used to decorate Brighton Pavilion, the Prince Regent's orientalist fantasy that was in many ways the equivalent of the Europeanstyle palaces of the Yuanmingyuan. ${ }^{135}$ Like the Qianlong emperor, the Prince Regent and his mother already had large collections of exotic items at the time of the embassy, and as in China the taste for such exotica was becoming old fashioned. Those few gifts that survive and can still be associated with the embassy have done so as beautiful items hidden away in royal collections.

China's military disasters in the mid-nineteenth century cannot be ascribed to a failure to interpret either the intention or the content of the gifts given during the Macartney embassy. The gifts given by both sides during the embassy were chosen against the background of a highly profitable trade between the two countries, emphasized the giver's wealth and power, and were part of the diplomacy between

\footnotetext{
${ }^{130}$ Christies, Catalogue of the First Part, Day 1 item 80.

${ }^{131}$ Christies, Catalogue of the First Part; Christies, Catalogue of the Remaining Part; Windsor, Royal Archives, GEO/ADD 2/88, List of Articles purchased at the sale of Her late Majesty's property; Roberts, George III and Queen Charlotte, p. 386.

132 Bodleian Library, MS Beckford c. 8 p. 103, Beckford to Franchi, 22 May 1819. (Translated from Italian).

${ }^{133}$ Christies, Catalogue of the First Part, Day 1 item 42. See also Christies, Catalogue of the Remaining Part, Day 1 item 54; B. McLeod, “A Celebrated Collector” in D.E. Ostergard ed. William Beckford, 1760-1844: An Eye for the Magnificent (New Haven: Yale University Press, 2001), pp. 156, 168. (Robert Hume, listed as buyer, was Beckford's agent).

134 John Rutter, Delineations of Fonthill and its Abbey (London: Charles Knight, 1823), p. 51.

135 Ayers, Chinese and Japanese Works, III. 842-868; J. Morley, The Making of the Royal Pavilion

Brighton: Designs and Drawings (London: Sotheby Publications, 1984), p. 25.
} 
them. The idea that the British gifts were seen as tribute by the Qianlong emperor at the time of the embassy is a reflection of European attitudes which were projected onto a Chinese term with a rather different meaning. Neither side attempted to understand the gifts in the terms that the giver intended. Instead, both aimed to use the gifts to display their own wealth and power and conciliate the recipients, as part of a diplomatic process through which they would achieve pragmatic negotiating goals that were closely connected to the trade, its profits and its taxation. In the aftermath of the embassy, the British did indeed blame their failure on the inability of the Chinese to understand their gifts, but for the Qing their reception of the embassy was a qualified success in warding off British pressure to change the terms of trade in the face of an immediate military threat. After the embassy the gifts entered the rulers' magnificent collections, which already contained many similar objects. There they were abstracted from their origins and from the meanings that the participants in the negotiations intended to give them, and were absorbed into their royal owner's wealth and splendour. The Opium War came nearly fifty years later and in response to very different circumstances on both sides: rising British global power and the obscurantist response of nineteenth century emperors whose power was much more constrained. 